\title{
Dialogue
}

Berths and Anchorages: Pacific Cultural Studies from Oceania LEA LANI KINIKINI KAUVAKA

Rethinking Pacific Studies Twenty Years On

TERENCE WESLEY-SMITH

The Contemporary Pacific, Volume 28, Number I, I29-169

(C) 2016 by University of Hawai' $i$ Press 


\section{Rethinking Pacific Studies \\ Twenty Years On}

Terence Wesley-Smith

I welcome this opportunity to reflect on developments in the field twenty years after my "Rethinking Pacific Islands Studies" article appeared in the journal Pacific Studies. ${ }^{1}$ It is interesting to note that Teresia Teaiwa's provocative essay "Scholarship from a Lazy Native" also appeared in 1995. Of course, our journeys to and through Pacific studies have been quite different (see Wesley-Smith 2004). However, we do at least share what Teaiwa described as "a deep ambivalence towards the scholarly or academic project, and an equally profound commitment to it," even if for different reasons (Teaiwa I995, 59). I cite Teaiwa's work at the beginning of this essay because I believe that she has done more than anyone else to advance our understanding of the intellectual contours of Pacific studies over the last two decades and, perhaps more important, to enhance pedagogical practice in this dynamic field.

\section{Studies in the Pacific or Pacific Studies?}

Discussions about Pacific studies (or Pacific Islands studies, as we still call it at the University of Hawai'i $[\mathrm{UH}]$ ) often become confused because of a basic distinction between a loose field of inquiry that embraces all studies in or about the region or its peoples, and one that is more circumscribed (D'Arcy 20II). My "Rethinking” article was explicitly focused on "organized, interdisciplinary programs of study that allow undergraduate and graduate students to major in Pacific Islands studies" and set out to explore the intellectual or academic foundations of such programs (Wesley-Smith I995, I I6). Implicit in this, of course, was a commitment to an emerging branch of scholarship defined by particular philosophical characteristics and practices that would distinguish it from what Teaiwa called

The Contemporary Pacific, Volume 28, Number I, I53-169

(C) 2016 by University of Hawai'i Press 
"any and all studies in or of the Pacific" and help guide appropriate forms of knowledge production about Oceania (Teaiwa 20I0, I I2). My purpose here is to identify trends and developments in more recent years that might help define what this particular version of Pacific studies is or should be (see Teaiwa 20II, 216).

It is not my intention to argue that the model of Pacific studies developed at the University of Hawai'i-which emphasizes reflexivity, indigenous epistemologies, and interdisciplinarity-is in any sense universal, and I certainly do not mean to suggest that it is superior to others. Indeed, more than a decade ago Stewart Firth identified what he saw as a distinction between Pacific studies programs in Hawai'i and New Zealand that are "mostly conceptualized as projects of cultural renaissance" and those in the independent Pacific that are conceived as projects "of modernization and development" (Firth 2003, I40). It is worth noting that Firth was teaching at the University of the South Pacific when he wrote this piece, and he had recently witnessed the upheavals and insecurities associated with the 2000 George Speight coup in Fiji and its appeal to indigenous rights as well as the violence resulting from the "tensions" in Solomon Islands. In such cases, Firth argued, "tradition" had become problematic rather than needing to be "retrieved or restored or maintained." Instead of asking "How can we understand the Pacific in ways that honor the past and reclaim the future for uniquely Pacific Island ways of doing things?" Firth suggested that at least in the independent Pacific a more appropriate fundamental research question was "How can we understand the region in ways that will make people better off?" (2003, I40).

In 2010, Cluny Macpherson echoed these sentiments when he argued that the "particular way of thinking and studying the Pacific" developed at the University of Hawai'i and spread through its professional networks did little to address a set of social, economic, and political issues "which impact on the lives of Pacific citizens daily." Furthermore, he argued that the approach ignored "other forms of interdisciplinarity" perhaps better equipped to understand these urgent regional problems (Macpherson 20IO). Macpherson is a sociologist with a distinguished career researching a variety of topics affecting Samoan communities at home and abroad, including issues of health, cultural identity, and economic development. In a major study, significantly titled The Warm Winds of Change, Macpherson, along with his wife and research partner, La'avasa Macpherson, documented the profound impacts of globalization on village life in Sāmoa (Macpherson and Macpherson 2009). However, unlike Firth, the 
Macphersons suggested that Samoan culture is dynamic and accommodating of social progress rather than acting as a barrier to making people "better off."

The major difference between these three approaches to scholarship, then, has much to do with the perceived need for a distinctive field of Pacific studies in the first place, with neither Firth nor Macpherson appearing to recognize significant conceptual, philosophical, or other limitations inherent in the practice of conventional social science in Pacific settings. But the main differences lie in the emphasis afforded traditional ways of being and knowing in the face of massive forces for change. Firth linked the different approaches to Pacific studies to different historical experiences, finding it understandable that indigenous peoples in Hawai'i and New Zealand gear their scholarly efforts toward grieving what is lost and toward retrieving, restoring, and celebrating what can be regained (Firth 2003, I39). One could argue, however, that this overwhelming sense of dispossession will become increasingly widespread as globalization intensifies its hold in other parts of the region.

Although I believe that the arguments put forward by Firth and Macpherson are open to challenge, I readily acknowledge the need for a pluralistic approach to Pacific studies research and teaching in the region. In this context, I applaud the organizers of the 2013 Pacific Studies symposium held in Nadi, Fiji, for their use of voyaging metaphors of "anchoring" and "berthing" to emphasize the idiosyncratic, place-based nature of the development of Pacific studies programs.

\section{(Re)thinking Pacific Studies}

No matter which approach we advocate, I would suggest that there remains an urgent need for much more reflexivity in our work. As Teaiwa put it: "Given the complexity of its available subject matter and the diversity of its manifestations, it is surprising that Pacific Studies has not been more consistent in generating a literature that reflects on its practice as well as its underlying theoretical or philosophical assumptions" (Teaiwa 20I0, I I2). This was surprising to me, too, when I was tasked with reviewing the curriculum of the University of Hawai'i's Pacific Islands Studies MA program in the early I990s. Although this program had been in place since I950, and several other centers had become established elsewhere in the I980s and I990s, I searched in vain for literature that would ground these initiatives intellectually and provide a coherent conceptual map for 
curriculum development. Apart from Ron Crocombe's mostly descriptive work on "Studying the Pacific" (I987), there was remarkably little that discussed Pacific studies as an institutionalized, interdisciplinary project. The wider literature on "area studies" in the United States, of which the UH program was part, also turned out to be short on academic content and long on funding and policy issues (see, eg, Goss and Wesley-Smith 20I0). I had to turn instead to some ongoing debates about practice and approach in the fields of history and anthropology, the two disciplines most influential in scholarship about the region. Perhaps most compelling were the ideological debates then gaining momentum in the expanding field of indigenous studies and their most important regional manifestations in Hawaiian studies and Māori studies. And, of course, there was Epeli Hau'ofa's landmark essay, "Our Sea of Islands," first debuted in Hawai'i in 1993, which laid out an inspiring new vision for the region (Hau'ofa 2008c).

The curriculum review marked a turning point in my academic career because it allowed me to identify more precisely the ambivalence I already felt toward the area studies approach. I began to realize that the spatial units of analysis we employed in the classroom were constructions emerging from the colonial history of the region; that the key concept structuring the curriculum was "social change," often conflated with ideas of development or modernization; and, perhaps most important, that the area studies enterprise was designed primarily to produce knowledge for external consumption and to serve external interests (see Wesley-Smith $2004,80-84$ ). On the other hand, the idea that a Pacific studies program such as ours could be reconstructed differently-to address rather than reproduce imbalances of power, to be of and for the region rather than simply about it-was one that served to renew my commitment to this type of scholarship. It is perhaps telling that shortly after the "Rethinking" piece came out in 1995, the Center for Pacific Islands Studies sponsored an international conference called "Contested Ground: Knowledge and Power in Pacific Islands Studies," the first of an ongoing series of conferences and workshops focused on the field of study itself. ${ }^{2}$

\section{Pragmatic and Laboratory Rationales For Pacific Studies}

Perhaps the most enduring legacy of the "Rethinking" article was the identification of three primary rationales for Pacific studies teaching and 
research. The first of these I called the "pragmatic rationale" to capture a program-building logic that emphasizes the need to know about the Pacific Islands places with which the metropolitan countries have to deal. Almost by definition this approach largely reflects the agendas, priorities, and perspectives of outsiders. It provided the dominant justification for the development of the UH program, as it did for numerous other areas studies programs across the United States, and their equivalents elsewhere, including Australia and New Zealand. Some of the many implications of this type of approach were explored by Greg Fry in his insightful study of the "doomsday" image of the Islands that emerged in Australian policy circles in the I990s. Fry argued that although such images said more about domestic perceptions and priorities than about conditions "out there," they assumed the authority of objective knowledge "on the basis of academic inquiry and the hard-headed realism and rationalism of the key areas of government and of the disciplinary focus of economics and demography" (Fry 1997, 307). Fry concluded by identifying some of the profound impacts of such ways of knowing:

The doomsdayists . . . are engaged in a system of knowledge that implicitly denies self-determination while claiming to advance it, and promotes superiority and exclusion while claiming to advance equality. At the heart of the new doomsdayism is the assumption of a special right to manage. (1997, 336)

I suggest that the doomsday image and the idea of the "special right to manage" remain alive and well in metropolitan centers of power two decades on, continuing to provide justification (and funding) for Pacificrelated research and teaching in universities and think tanks on topics of interest to policy makers. Although the topics themselves are wideranging, they include a special focus on state and nation building, governance, and development. Ultimately they reflect an overriding concern for regional security and stability. The pragmatic rationale for Pacific studies has, no doubt, received a boost as a result of the rise of China in Oceania and the reworking of long-established networks of power and influence in the region presently underway (see eg, Wesley-Smith 20I3). It is also interesting to note that China's first national research center for this part of the world, the Center for Oceania Studies, opened for business in 2013 at Sun Yat-sen University in Guangzhou, and the Chinese University of Hong Kong hosted its first academic conference on Sino-Pacific relations in March 2014.

If the pragmatic rationale often has more to do with influence than 
understanding, the "laboratory rationale" values the Pacific Islands and Pacific Islanders primarily as objects for study. This approach is most apparent in fields like anthropology and linguistics where the ultimate objective is not only or even primarily to engage with a particular society or language but rather to contribute to an esoteric body of knowledge. Although anthropologists rightly claim that their work has many practical and beneficial local applications, these efforts are not always appreciated by studied communities. In an early article discussing the source of such disjuncture, Epeli Hau'ofa (himself trained in anthropology) identified the esoteric nature of anthropological discourse as a major problem:

When we produce our articles and monographs and [members of studied communities] and their children or grandchildren read them, they often cannot see themselves or they see themselves being distorted and misrepresented.... our field of discourse, and our special social science language, preclude any comprehension of what we are talking about. (Hau'ofa 2008a, 4; see also Smith 1999)

Perhaps more important, Hau'ofa pointed to "the rigours of an uncompromising empiricism and other Western intellectual traditions" that distort understanding of Pacific cultures. He called for the inclusion of intuitive knowledge and "feel" for the subtleties of cultures and relationships: "We must devise ways . . to tap instead of suppress the subjectivity to which I have referred and thereby humanise our study of the condition of the peoples and cultures of the Pacific" (Hau'ofa 2008a, 9).

Almost four decades later, Hawaiian scholar Ty Kāwika Tengan still struggles with a profound ambivalence toward the discipline of anthropology of which he is part. In his keynote address at the 2014 meeting of the Association for Social Anthropology in Oceania (ASAO) held in Kona, Hawai'i, Tengan decried what he perceived as a culture of privilege, "especially the privilege of not having to deal on a daily basis with the profound cultural, economic, social, and political consequences of colonialism," and, like Hau'ofa, yearned for the creation of "meaningful connections that acknowledge and viscerally engage Indigenous time, space, and place" (Tengan and Roy 20I4, 3 I8, 3I 7).

As evidenced by the large number of participants at recent professional gatherings such as those hosted by ASAO and the European Society for Oceanists (ESFO), interest in this quintessentially Western scientific approach to Pacific studies shows no sign of abating. However, there is a heightened awareness of issues of positionality, research ethics, and 
the politics of knowledge. Sponsorship for Pacific Islander academics and public intellectuals to participate at these events has increased, and, most significant, disciplinary subbranches like indigenous anthropology, specifically designed to work through complex epistemological and political entanglements, have emerged. A special issue of Pacific Studies edited by Ty Tengan, Tēvita Ka'ili, and Rochelle Fonoti explores the history of and current practice in this vibrant offshoot of Pacific anthropology (Tengan, Ka'ili, and Fonoti 20I0; see also, eg, White and Tengan 200I; Tengan 2005). But despite these modifications and accommodations, the perception that this type of inquiry is generally about but not for Pacific Islanders is likely to persist.

\section{EMPOWERMENT}

Of course, a major purpose of the "Rethinking" article was to advocate for the primacy of the "empowerment rationale" in Pacific studies program development. The article notes that more indigenous voices and perspectives in curriculum and research are a necessary part of decolonization, but it argues that greater indigenous participation is not in itself sufficient. I identified the main impediment to progress as the way social science is practiced, rather than who is practicing it, and advocated a radically different type of Pacific studies scholarship, one more firmly grounded in indigenous experience and ways of knowing. I went on to suggest a link between decolonization and the interdisciplinary approach that I also argued should be an essential part of a reformed Pacific studies: "In a sense, decolonization is an inherent part of the business of becoming interdisciplinary, in that this process requires the critical scrutiny of established modes of inquiry. This approach allows ethnocentric aspects of orthodox approaches to be identified and facilitates the incorporation of indigenous epistemologies and perspectives" (Wesley-Smith I995, I29).

In retrospect, my faith in the liberating promise of both interdisciplinarity and indigeneity - as well as the link between the two-was premature, perhaps even naive. More than a decade later, in 2008, Graeme Whimp surveyed existing Pacific studies programs, including his own at Victoria University of Wellington, and found "no evidence of the existence of a working model ... that substantially accommodates" an interdisciplinary orientation (2008, 4II). Even worse, he argued that even if such a model did exist it would probably struggle to engage with indigenous knowledge systems simply because their respective ontological foundations are simply 
too different from each other. Breaking down or working across the barriers between Western disciplinary traditions to create what Guy Berger called an "interdisciplinary archipelago" (1972, 23) based on a common set of axioms would likely still find itself at odds with non-Western knowledge systems resting on fundamentally different philosophical premises (Whimp 2008, 403-404, 4IO-4II).

I still believe as I did in I 995 that the creation of systematized bodies of knowledge rooted in indigenous histories and cultures "on which more appropriate forms of scholarship can be based" is a worthy, even essential, long-term aspiration for Pacific studies. But whether this is a realistic goal is another matter entirely. In retrospect, my caution about the "many obstacles to the indigenization of academic discourse" seems inadequate, to say the least (Wesley-Smith I995, I26). A large part of the problem is the hegemonic and often invisible qualities of Western-generated discourse about non-Western areas, peoples, and problems. Western ways of knowing and ideas of "progress" have become privileged to a degree that is quite astounding, considering the myriad other ways societies have defined their realities over the long span of human history. In a fascinating survey of what she calls "southern theory," Raewyn Connell argued that modern social science "embeds the viewpoints, perspectives and problems of metropolitan society, while presenting itself as universal knowledge" (2007, vii-viii). She noted that although alternative ways of thinking about the world persist, they are often marginalized, "intellectually discredited, dropped from the curricula of schools and universities, or ripped off by corporations seeking intellectual property rights" (Connell $2007, \mathrm{xi})$. Connell sought to identify local forms of knowledge and to treat them as theory, as texts to "learn from, not just about" (2007, vii). In the end, though, Connell was cautious about the prospects of "reconfiguring knowledge on a world scale," noting that current alternatives to the metropolitan dominance of social science remain unstable and that the methods for intellectual work across regions and traditions of thought are not yet well established $(2007,232)$.

\section{Indigenous Knowledge and PaCific ScholarshiP}

Some of these issues are apparent in Oceania. Over the last two decades there has been a remarkable expansion in the number of individuals of Pacific ancestry participating in higher education, including in Pacific studies programs across the region, and an increasing number of instruc- 
tors and university administrators with genealogical connections to the Islands. The volume of indigenous scholarship appearing in books and professional journals has also expanded significantly, and the efflorescence of creative work by Pacific poets, writers, visual artists, and filmmakers has been even more impressive. Epeli Hau'ofa's call for indigenous peoples to regain control of representations of the peoples and cultures of Oceania from "people with powerful connections" has clearly been answered, to an extent that he himself might have found surprising (Hau'ofa 2008d, 60). Especially encouraging is the work of Pacific scholars who have engaged seriously with epistemological issues, including Konai Helu Thaman (eg, 2003), David Welchman Gegeo (eg, I998, and with Watson-Gegeo 200I), Manulani Aluli Meyer (eg, 200I), Elise Huffer and Ropate Qalo (2004), Unaisi Nabobo-Baba (2006), and Subramani (eg, 200I). Indeed, in 2006 the University of the South Pacific hosted a major conference called "Vaka Vuku: Navigating Knowledge," which focused on Pacific epistemologies, yielding important papers. ${ }^{3}$

And yet the dream of a systemized body of indigenous knowledge on which Pacific studies scholarship might be based remains elusive, in part because the work is really only beginning but largely because of the very cultural and linguistic diversity that is a central characteristic of this vast oceanic realm. There is a plethora of native epistemologies animating the village communities of Oceania and no single language to access them adequately. Furthermore, as Houston Wood and others have pointed out, many of those working to distill the essence of indigenous knowledges are doing so in the context of local or national identities and, in settler colonies like Hawai'i, Aotearoa, and Guam, in order to promote sovereignty agendas. They are often not ready or inclined to reach across cultural boundaries, which themselves have been hardened by the colonial experience (Wood 2003). Some of the giants in the canon of Pacific studies, including Albert Wendt (I976), Subramani (200I), and Epeli Hau'ofa (2008c [1993], 2008b [1997], 2008d [2000]), have articulated powerful transcendent visions for Oceania, and in many ways the Oceania Centre for Arts and Culture at the University of the South Pacific in Fiji is emblematic of this aspiration. However, it is worth noting that a regional imaginary is as yet not widely shared, except among a handful of artists and academics, and is largely absent at the grassroots level. Meanwhile, the architects of Pacific studies programs will have to engage with a more diffuse and fragmented epistemological landscape than they might like. As Whimp put it, Pacific studies might have to "be as inter-Native as it is 
inter-disciplinary, with as much slipperiness in the former term as the latter" (2008, 4II).

On the other hand, perhaps the goal of a comprehensive body of indigenous knowledge is itself misplaced and reflects a type of essentialism that we are quick to condemn in other academic contexts. In an often-cited article first published in 1994, for example, Vilsoni Hereniko argued that Pacific identities—and by extension the cultures they reflect-are fluid, dynamic, contested, and negotiable: "The present search for cultural identities rooted in the past but relevant in the present has to be carefully conducted, if self-determination for individuals, nations, and the Pacific region is to be a reality" (Hereniko I994, 430). Hau'ofa made a similar point in his "Pasts to Remember" essay, this time explicitly addressing knowledge systems. A positive attribute of Oceanic societies, he claimed, is that "truth is flexible and negotiable, despite attempts by some of us to impose political, religious, and other forms of absolutism.... There are no final truths or falsehoods, only interpretations, temporary consensus, and even imposition, for particular purposes" (Hau'ofa 2008d, 6I). For Hau'ofa, then, the issue was not that knowledge systems are diverse or, as Whimp put it, slippery. For him the key questions had to do with who owns these truths and whose interests are served by them.

While ostensibly an exploration of the history and nature of female clowning in Rotuma, Hereniko's landmark 1995 monograph Woven Gods is really an exploration of competing forms of knowledge production. Rather than dismissing relevant Western scholarship, he embraced it, but he insisted that indigenous epistemologies be brought to bear as well. "It is time," he argued, "for Pacific Islanders to infuse western scholarship with their own ways of being and doing" (Hereniko I995, I40). The findings of the book are informed by multiple sources, including "subjective and objective accounts, intuition and dreams" (Hereniko I995, 8-9). As with any innovative work, Woven Gods is by no means without its flaws. One reviewer complained that "to read the book is to veer clumsily among a farrago of data and styles" (Mitchell I997, 280), and others might claim that the text says more about the author's own creativity (and playfulness) than about indigenous scholarship more generally. Nevertheless, Woven Gods does represent a robust challenge to prevailing assumptions about knowledge production and offers lessons in how scholarly practices might be decolonized.

Other scholars have followed Hereniko's emphasis on creativity in Pacific studies and its role in indigenous empowerment. For example, in 
a recent MA thesis in Pacific Islands studies, Leora Kava summarized her approach to knowledge production in Tonga: "Within the literature and ideology of Pacific Islands Studies, I defined decolonization as the critical consciousness of Pacific Islander representation within the ongoing legacies of colonial constructions; the translation of that consciousness into actions that reclaim our own representation; and the approach to that reclamation through creativity and imagination that have always been part of our genealogies and epistemologies as Pacific peoples" (Kava 20I 5, 64).

Two decades after the "Rethinking" article appeared, few would challenge the central place of the empowerment rationale in Pacific studies. But exactly what "empowerment" means and how it can best be realized remains contested (see Kauvaka, this issue). What is heartening, however, is how emerging scholars like Kava are building on the intellectual and ideological foundations established by Albert Wendt, Epeli Hau'ofa, Konai Thaman, Vilsoni Hereniko, and others to create new forms of scholarship that are rigorous, refreshing, and restorative.

\section{New Approaches}

When all is said and done, there is nothing sacrosanct about interdisciplinarity in Pacific studies, as my "Rethinking" article might have suggested. Instead, it can be seen as a more-or-less useful intellectual device for countering the bounded, limited, and hegemonic nature of traditional disciplines, a heuristic tool for "opening up new approaches to the issues of concern to the people of the Pacific" (Whimp 2008, 4I4). At the Center for Pacific Islands Studies, we have attempted to do just that in recent decades. One of the core seminars in our MA program, PACs 60I Learning Oceania, addresses issues in the field of study itself, including the ones surveyed here, while another, PACs 602 Re/Presenting Oceania, examines competing representations of the region with an emphasis on the counter-narratives produced by indigenous scholars, writers, artists, and filmmakers. A third, PACs 603 Researching Oceania, helps students devise appropriate methods for their research activities and select appropriate media to convey the results. We have also added an MA Portfolio option as an alternative to the more conventional written thesis, allowing students to use a range of electronic, visual, performative, or creative media to help express the knowledge they have constructed. ${ }^{4}$

Teresia Teaiwa has suggested that in addition to interdisciplinarity and accounting for indigenous knowledge, a third essential element for Pacific 
studies is comparative analysis (2010, I I 7). Apart from the intrinsic value of a comparative approach, her purpose in this is to discourage narrowly focused engagement with home communities—and the identity-driven scholarship that may result. "What is wrong with the empowerment rationale as we have seen it develop in Pacific Studies," she argued, "is the lack of honest indigenous analysis" (Teaiwa 2010, II7). She wants her students to engage in "deep learning," to engage creatively and critically with Pacific materials, indigenous or otherwise (Teaiwa 20II, 2I9). Even though we at the University of Hawai'i have yet to explore these pedagogical issues in the same depth, the theme-driven nature of all of our undergraduate offerings serves to encourage our students to think comparatively. We have not been as successful at the graduate level where, often for practical reasons like time constraints, most of our MA students produce work focused on a single ethnic group or location.

Another aspect of empowerment that has emerged at our center in recent years is a commitment to engage in more meaningful ways with expanding diasporic communities in Hawai' $i$, particularly those originating in the Marshall Islands and the Federated States of Micronesia. Indeed, a major rationale for establishing an undergraduate program in Pacific Islands studies in 20I I was to address the academic needs of these migrant groups, often underrepresented on campus and at higher risk of failing to complete a program of study. Most of the students who go on from the introductory level Pacific Worlds class (PACS IO8) to take our 200-, 300-, and 400-level courses, and almost all of those who declare Pacific Islands studies as their major, are so-called heritage students who have grown up in Hawai'i or on the US continent. The degree itself includes a track or specialty focused on issues affecting diasporic communities, and all students are required to participate in service-learning outreach to these communities as part of their degree requirements.

\section{Pacific Studies and the Space Between}

For the foreseeable future, as Whimp suggested (2008, 4I 2), Pacific studies will of necessity exist in the vā, "the space between, the separation that connects," navigating choppy waters between rationales, disciplines, knowledges, identities, lands, peoples, and cultures. Despite all of its instability and uncertainty, however, Pacific studies has become a vital academic space to encourage deep learning, promote creativity and understanding, generate counter-hegemonic discourse, and nurture personal growth 
and self-determination. At the end of her first semester in the MA program, a student with genealogical connections to both Tahiti and Hawai' $i$ wrote:

These past I 6 weeks took years in the making for me, and then I blinked, and it was gone. I expected to learn about the Pacific region, but I did not expect to feel that the region was a part of me. I expected to read a lot. But I did not expect those readings to change the way I see the world or how they would shape my understanding of my place in its vastness. I expected to do research papers, but I did not expect to find empowerment in the words and artwork of the beautiful Pacific. I expected to gain new knowledge. But I did not expect to find myself immersed in valuable indigenous epistemology. I expected to meet new people. But I did not expect to find the rich diversity inspirational and influential. I expected to contribute in class discussions, but I did not expect to feel the weight of the responsibility to produce scholarship that would benefit my family, my community, and my people. ... I expected to start the Master's Program in Pacific Islands Studies; but I truly did not expect to be transformed by the journey. (pers comm, Dec 2013)

Another student in the same cohort, a Chamorro from Guam, perhaps put it best during a discussion about the field of study. "What matters most to me," he said, "is that this is our space" (pers comm, October 20I3). Sentiments such as these confirm my commitment to an expanding and diversifying Pacific studies project, and they serve to counter any tendencies to complacency twenty years on.

\section{Notes}

I This paper is a revised version of an invited address delivered at the "Oceanic Symposium," hosted by the Oceania Centre for Arts, Culture and Pacific Studies, University of the South Pacific, and held at the Nadi Bay Resort Hotel, Fiji, 6-7 November 20I3. Special thanks to Alex Mawyer, who offered extensive and useful comments on an earlier draft.

2 Other conferences and workshops sponsored by our center have included "Remaking Asia Pacific Studies: Knowledge, Power, and Pedagogy" (2002); "Learning Oceania: Towards a PhD Program in Pacific Studies" (2003); "Learning Islands: A Workshop for Instructors in Pacific and Caribbean Studies" (2004); and "Celebrating Connections: 60 Years of Pacific Studies" (2010). See also Teaiwa $200 \mathrm{I}$.

3 See the "Vaka Vuku" conference website at http://www.usp.ac.fj/index.php ?id=I35I [accessed 2I July 20I5]. 
4 It is worth noting that one of two recent faculty hires in the center, Moana Nepia, is a dancer, choreographer, writer, and artist whose creative practice-led doctorate used methodology grounded in mātauranga and tikanga Māori knowledge systems.

\section{References}

Berger, Guy

I972 Introduction. In Interdisciplinarity: Problems of Teaching and Research in Universities, edited by Léo Apostel, Guy Berger, and Guy Michaud, 23-26. Paris: Organisation for Economic Co-operation and Development.

Connell, Raewyn

2007 Southern Theory: The Global Dynamics of Knowledge in Social Science. Cambridge: Polity Press.

Crocombe, Ron

I987 Studying the Pacific: Past Experience and Future Potentials. In Class and Culture in the South Pacific, edited by Antony Hooper and others, I I 5-I 39. Auckland: Center for Pacific Studies, University of Auckland; Suva: Institute of Pacific Studies, University of the South Pacific.

D'Arcy, Paul

201 I The Teaching of Pacific History: Introduction. The Journal of Pacific History 46 (2): 197-206.

Firth, Stewart

2003 Future Directions for Pacific Studies. The Contemporary Pacific I $5:$ I $39-$ I 48 .

Fry, Greg

I997 Framing the Islands: Knowledge and Power in Changing Australian Images of "The South Pacific." The Contemporary Pacific 9:305344 .

Gegeo, David Welchman

I998 Indigenous Knowledge and Empowerment: Rural Development Examined from Within. The Contemporary Pacific Io:289-3 I 5.

Gegeo, David Welchman, and Karen Watson-Gegeo

200I "How We Know": Kwara'ae Rural Villagers Doing Indigenous Epistemology. The Contemporary Pacific I 3:5 5-88.

Goss, Jon, and Terence Wesley-Smith

2010 Remaking Area Studies. In Remaking Area Studies: Teaching and Learning Across Asia and the Pacific, edited by Terence Wesley-Smith and Jon Goss, ix-xxvii. Honolulu: University of Hawai'i Press. 
Hau'ofa, Epeli

2008a Anthropology and Pacific Islanders. In We Are the Ocean: Selected Works, 3-Io. Honolulu: University of Hawai'i Press. Originally published in Oceania 45:283-289 (I975).

$2008 \mathrm{~b}$ The Ocean in Us. In We Are the Ocean: Selected Works, 4I-59. Honolulu: University of Hawai'i Press. Originally published in Dreadlocks in Oceania I:I24-I48 (I997).

2008c Our Sea of Islands. In We Are the Ocean: Selected Works, 27-40. Honolulu: University of Hawai'i Press. Originally published in $A$ New Oceania: Rediscovering Our Sea of Islands, edited by Eric Waddell, Vijay Naidu, and Epeli Hau'ofa, 2-I6. Suva: School of Social and Economic Development, University of the South Pacific (I993).

2008d Pasts to Remember. In We Are the Ocean: Selected Works, 60-79. Honolulu: University of Hawai'i Press. Originally published in Remembrance of Pacific Pasts: An Invitation to Remake History, edited by Robert Borofsky, 453-472. Honolulu: University of Hawai'i Press (2000).

Hereniko, Vilsoni

I994 Representations of Cultural Identities. In Tides of History: The Pacific Islands in the Twentieth Century, edited by K R Howe, Robert C Kiste, and Brij V Lal, 406-434. Honolulu: University of Hawai'i Press. Reproduced in Inside Out: Literature, Cultural Politics, and Identity in the New Pacific, edited by Vilsoni Hereniko and Rob Wilson, I37-I66. Lanham, MD: Rowman \& Littlefield (I999).

I995 Woven Gods: Female Clowns and Power in Rotuma. Pacific Islands Monograph Series I 2. Honolulu: Center for Pacific Islands Studies and University of Hawai'i Press.

Huffer, Elise, and Ropate Qalo

2004 Have We Been Thinking Upside-Down? The Contemporary Emergence of Pacific Theoretical Thought. The Contemporary Pacific I 6:87-I I 6 .

Kava, Leora

2015 In Our Own Verse: Tongan Music and Poetry Writing as Decolonial Praxis. MA Portfolio, Center for Pacific Islands Studies, University of Hawai'i at Mānoa.

Macpherson, Cluny

2010 Conference Comments. Blog entry on conference website, "Celebrating Connections: 60 Years of Pacific Studies,” 4-6 November, University of Hawai'i at Mānoa. http://celebratingconnections.blogspot .com/ [accessed I 6 July 20I 5 ] 
Macpherson, Cluny, and La'avasa Macpherson

2009 The Warm Winds of Change: Globalisation in Contemporary Samoa. Auckland: Auckland University Press.

Meyer, Manulani Aluli

200I Our Own Liberation: Reflections on Hawaiian Epistemology. The Contemporary Pacific I3:I24-I48.

Mitchell, William

I997 Review of Woven Gods: Female Clowns and Power in Rotuma, by Vilsoni Hereniko. The Contemporary Pacific 9:279-28I.

Nabobo-Baba, Unaisi

2006 Knowing and Learning: An Indigenous Fijian Approach. Suva: Institute of Pacific Studies, University of the South Pacific.

Smith, Linda Tuhiwai

I999 Decolonizing Methodologies: Research and Indigenous People. New York: Zed Books.

Subramani

200I The Oceanic Imaginary. The Contemporary Pacific I3:I49-I62.

Teaiwa, Teresia

I995 Scholarship from a Lazy Native. In Work in Flux, edited by Emma Greenwood, Klaus Neumann, and Andrew Sartori, 58-72. Melbourne: History Department, the University of Melbourne.

200I L(o)osing the Edge. The Contemporary Pacific I3:343-357.

2010 For or Before an Asia Pacific Studies Agenda? Specifying Pacific Studies. In Remaking Area Studies: Teaching and Learning Across Asia and the Pacific, edited by Terence Wesley-Smith and Jon Goss, I IO-I 24. Honolulu: University of Hawai'i Press.

20I I Preparation for Deep Learning: A Reflection on "Teaching” Pacific Studies in the Pacific. The Journal of Pacific History 46 (2): 2I4220.

Tengan, Ty Kāwika

2005 Unsettling Ethnography: Tales of an 'Ōiwi in the Anthropological Slot. Anthropological Forum I 5 (3): 247-256.

Tengan, Ty Kāwika, and Lamaku Mikahala Roy

2014 "I Search for the Channel Made Fragrant by the Maile": Genealogies of Discontent and Hope. Oceania 84 (3): 3 I 5-330.

Tengan, Ty Kāwika, Tēvita O Ka'ili, and Rochelle Tuitagava'a Fonoti, editors 2010 Genealogies: Articulating Indigenous Anthropology in/of Oceania. Special issue of Pacific Studies 33 (2-3).

Thaman, Konai Helu

2003 Decolonizing Pacific Studies: Indigenous Perspectives, Knowledge and Wisdom in Higher Education. The Contemporary Pacific I 5:II7. 
Wendt, Albert

I976 Towards a New Oceania. Mana I:49-69.

Wesley-Smith, Terence

I995 Rethinking Pacific Islands Studies. Pacific Studies I 8 (2): I I 5-I 37.

2004 The Ocean in Me. In Pacific Places, Pacific Histories, edited by Brij Lal, 70-86. Honolulu: University of Hawai'i Press.

2013 China's Rise in Oceania: Issues and Perspectives. Pacific Affairs 86

Whimp, Graeme (2): $35 \mathrm{I}-372$.

2008 Interdisciplinarity and Pacific Studies: Roots and Routes. The Contemporary Pacific 20:397-42I.

White, Geoffrey M, and Ty Kāwika Tengan

200I Disappearing Worlds: Anthropology and Cultural Studies in Hawai' 1 and the Pacific. The Contemporary Pacific I3:38 I-4I 6 .

Wood, Houston

2003 Cultural Studies for Oceania. The Contemporary Pacific I 5:340374 .

\section{Abstract}

This essay reflects on developments in the field since the I995 publication of "Rethinking Pacific Islands Studies" first explored a number of intellectual or academic foundations of such programs. It suggests that the pragmatic rationale for Pacific studies, which often has more to do with influence than understanding, and the laboratory rationale, which values Pacific Islanders primarily as objects of study, are both alive and well twenty years on, albeit with more attention among practitioners to issues of positionality, research ethics, and the politics of knowledge. The essay discusses the challenges of realizing the empowerment rationale advocated in the original article but argues that there has been some progress in giving primacy to indigenous perspectives, interests, and epistemologies in Pacific studies scholarship. The essay concludes with a discussion of how the empowerment rationale has informed curriculum and program development at the Center for Pacific Islands Studies at the University of Hawai'i-Mānoa over the past two decades.

KEYWORDS: Pacific studies, epistemology, indigenous knowledge, curriculum development 